\title{
PERCENTAGE CONTRIBUTION OF INCREASED HEART RATE TO INCREASED OXYGEN TRANSPORT DURING ACTIVITY IN PSEUDEMYS SCRIPTA, TERRAPENE ORNATA AND OTHER REPTILES
}

\author{
ROBERT E. GATTEN, JR.*
}

Department of Zoology, The University of Michigan, Ann Arbor, Michigan 48104 U.S.A.

(Received $16 \mathfrak{F u l y ~ 1 9 7 3 )}$

\begin{abstract}
A new formula which correctly expresses the percentage contribution of increased heart rate to increased oxygen transport during activity is presented.

2. The percentage contribution is reported for the turtles Pseudemys scripta and Terrapene ornata at body temperatures of $10-40^{\circ} \mathrm{C}$.

3. Corrected values for this parameter in reptiles studied at $30^{\circ} \mathrm{C}$ by other authors are also presented.
\end{abstract}

SEVERAL recent physiological studies have included simultaneous measurements of metabolic rate and heart rate of resting and active reptiles. Bartholomew \& Tucker (1963) presented an equation which they felt expressed the relative change of metabolism and heart rate during activity, a parameter which they termed the percentage contribution of increased heart rate to increased oxygen transport during activity. The equation which these authors derived from the Fick equation for this parameter is

$$
\% \text { contribution }=\left(\frac{\mathrm{AHR}-\mathrm{SHR}}{\mathrm{SHR}}\right) \div\left(\frac{\mathrm{AHR}-\mathrm{SHR}}{\mathrm{SHR}}+\frac{\mathrm{AOP}-\mathrm{SOP}}{\mathrm{SOP}}\right)
$$

where AHR, SHR, AOP and SOP are active and standard heart rate and oxygen pulse, respectively. This equation, however, overestimates the percentage contribution because the denominator of the right-hand side of the equation

$$
\left(\frac{\mathrm{AHR}-\mathrm{SHR}}{\mathrm{SHR}}+\frac{\mathrm{AOP}-\mathrm{SOP}}{\mathrm{SOP}}\right)
$$

docs not represent the actual fractional change in oxygen transport during activity, i.e. metabolic scope (active metabolic rate minus standard metabolic rate) divided by standard metabolic rate. Consider the hypothetical case where

$$
\begin{array}{rll}
\mathrm{SMR}=10, & \mathrm{SHR}=5, & \mathrm{SOP}=2, \\
\mathrm{AMR}=40, & \mathrm{AHR}=15, & \mathrm{AOP}=2 \cdot 67,
\end{array}
$$

* Present address: Department of Biology, The College of Wooster, Wooster, Ohio 44691, U.S.A. 
in which SMR and AMR are standard and active metabolic rate, respectively. Note that metabolic rate equals heart rate times oxygen pulse at rest and during activity. According to Bartholomew \& Tucker's (1963) equation

$$
\begin{aligned}
\% \text { contribution } & =\left(\frac{15-5}{5}\right) \div\left(\frac{15-5}{5}+\frac{2 \cdot 67-2}{2}\right) \\
& =0.86
\end{aligned}
$$

It should be noted that the right-hand side of Bartholomew $\&$ Tucker's equation should be multiplied by 100 to yield an actual percentage rather than a decimal fraction. A new equation is proposed here which is a true representation of the percentage contribution of increased heart rate to increased oxygen transport:

$$
\% \text { contribution }=\left[\left(\frac{\mathrm{AHR}-\mathrm{SHR}}{\mathrm{SHR}}\right) \div\left(\frac{\mathrm{AMR}-\mathrm{SMR}}{\mathrm{SMR}}\right)\right] \times 100 \text {. }
$$

Rearranged, this equation becomes

$$
\% \text { contribution }=\left(\frac{\mathrm{HRI} \times \mathrm{SMR}}{\mathrm{SHR} \times \mathrm{Scope}}\right) \times 100,
$$

where

HRI (heart rate incrcment) $=$ AHR - SHR and Scopc $=$ AMR - SMR.

Using the hypothetical case

$$
\begin{aligned}
\% \text { contribution } & =\left(\frac{10 \times 10}{5 \times 30}\right) \times 100 \\
& =67 .
\end{aligned}
$$

Table 1 presents the values for this parameter based on metabolic and heart rate data for the turtles P. scripta and T. ornata (Gatten, 1974). This percentage

Table 1-Percentage contribution of increased heart rate to increased oxygen TRANSPORT DURING ACTIVITY IN $P$. scripta AND $T$. ornata

\begin{tabular}{ccc}
\hline & \multicolumn{2}{c}{ Percentage contribution } \\
\cline { 2 - 3 }$\left.T_{\mathrm{b}} \mathrm{C}\right)$ & P. scripta & T. arnata \\
\hline 10 & 6 & 27 \\
15 & 8 & 35 \\
20 & 9 & 21 \\
25 & 10 & 13 \\
30 & 11 & 14 \\
35 & 12 & 23 \\
40 & 13 & 35 \\
\hline
\end{tabular}

Values were calculated using Equation 3 and standard and active metabolic and heart rates from Gatten (1974). 
is always lower in $P$. scripta than in $T$. ornata, which indicates that increased cardiac frequency contributes less and increased oxygen pulse contributes more to oxygen demand during activity in the former than the latter species. This parameter increases steadily with rising body temperature in $P$. scripta, whereas it reaches a minimum value at $25-30^{\circ} \mathrm{C}$ and maximum values at lower and higher body temperatures in $T$. ornata.

Table 2 summarizes information on the percentage contribution of increased heart rate to increased oxygen transport during activity in a number of reptiles at $30^{\circ} \mathrm{C}$. This parameter is lower in $P$. scripta than in any other reptile studied

Table 2-Percentage contribution of increased heart rate to increased oxygen TRANSPORT DURING ACTIVITY IN REPTILES AT $30^{\circ} \mathrm{C}$

\begin{tabular}{lccl}
\hline \multicolumn{1}{c}{ Species } & $\begin{array}{c}\text { Percentage } \\
\text { contribution } \\
\text { [equation (3)] }\end{array}$ & $\begin{array}{c}\text { Percentage } \\
\text { contribution } \\
\text { [equation (1)] }\end{array}$ & \multicolumn{1}{c}{ Reference } \\
\hline Amphibolurus barbatus & 36 & 46 & Bartholomew \& Tucker (1963) \\
Egernia cunninghami & 21 & 34 & Wilson (1971) \\
Iguana iguana & 14 & 18 & Moberly (1968) \\
Physignathus lesueuri & 20 & 33 & Wilson (1971) \\
Pituophis catenifer & 15 & 30 & Greenwald (1971) \\
Pseudemys scripta & 11 & 29 & Present study \\
Sauromalus hispidus & 24 & 51 & Bennett (1972) \\
Spalerosophis cliffordi & 19 & 24 & Dmi'el \& Borut (1972) \\
Sphenodon punctatum & 13 & 11 & Wilson \& Lee (1970) \\
Terrapene ornata & 14 & 42 & Present study \\
Tiliqua rugosa & 37 & 58 & Wilson (1971) \\
Tiliqua scincoides & 34 & 46 & Bartholomew et al. (1965) \\
Varamus gouldii & 12 & 19 & Bennett (1972) \\
Varantis spp. & 23 & 33 & Bartholomew \& Tucker (1964) \\
\hline
\end{tabular}

Values were calculated using Equation 3 and Equation 1 of Bartholomew \& Tucker (1963).

previously at $30^{\circ} \mathrm{C}$. This implies that a relatively great change in cardiac stroke volume and/or arterial-venous oxygen difference occurs with activity in this species. Equation 3 gives substantially lower values for this parameter than does Equation 1 of Bartholomew \& Tucker (1963), except in the case of Sphenodon punctatum where the percentage contribution is lower than in any other species.

Acknowledgements-This paper is a portion of a dissertation submitted in partial fulfillment of the requirements for the degree of Doctor of Philosophy in Zoology in The University of Michigan. The work was completed under the supervision of Dr. William R. Dawson, who generously provided me with access to his laboratory and equipment. Drs. Carl Gans, Karl F. Guthe and Conrad S. Yocum offered helpful suggestions and 
provided constructive comments during this study and during the preparation of this paper. I am grateful to the Department of Zoology of the University of Michigan for providing financial assistance, facilities and equipment. I thank Janet Cooper for typing the manuscript.

\section{REFERENCES}

Bartholomew G. A. \& Tucker V. A. (1963) Control of changes in body temperature, metabolism, and circulation by the agamid lizard, Amphibolurus barbatus. Physiol. Zoöl. 36, 199-218.

Bartholomew G. A. \& Tucker V. A. (1964) Size, body temperature, thermal conductance, oxygen consumption, and heart rate in Australian varanid lizards. Physiol. Zoöl. 37, 341-354.

Bartholomew G. A., Tucker V. A. \& LeE A. K. (1965) Oxygen consumption, thermal conductance, and heart rate in the Australian skink, Tiliqua scincoides. Copeia 1965, 169-173.

BENNETT A. F. (1972) The effect of activity on oxygen consumption, oxygen debt, and heart rate in the lizards Varanus gouldii and Sauromalus hispidus. F. comp. Physiol. 79, 259-280.

DMi'EL R. \& BoRUt A. (1972) Thermal behavior, heat exchange, and metabolism in the desert snake Spalerosophis cliffordi. Physiol. Zoöl. 45, 78-94.

GATTEN R. E., JR. (1974) Effects of temperature and activity on aerobic and anaerobic metabolism and heart rate in the turtles Pseudemys scripta and Terrapene ornata. Comp. Biochem. Physiol. 48A, 619-648.

GreEnWALd O. E. (1971) The effect of body temperature on oxygen consumption and heart rate in the Sonora gopher snake, Pituophis catenifer affinis Hallowell. Copeia 1971, 98-106.

Moberly W. R. (1968) The metabolic responses of the common iguana, Iguana iguana, to activity under restraint. Comp. Biochem. Physiol. 27, 1-20.

WILsoN K. J. (1971) The relationships of activity, energy, metabolism, and body temperature in four species of lizards. Ph.D. dissertation, Monash University, Australia.

Wilson K. J. \& LeE A. K. (1970) Changes in oxygen consumption and heart-rate with activity and body temperature in the tuatara, Sphenodon punctatum. Comp. Biochem. Physiol. 33, 311-322.

Key Word Index-Metabolic rate; oxygen consumption; heart rate; oxygen pulse; oxygen transport; activity; reptiles; turtles; Pseudemys scripta; Terrapene ornata. 